www.jmscr.igmpublication.org

Index Copernicus Value: 79.54

ISSN (e)-2347-176x ISSN (p) 2455-0450

crossref DOI: https://dx.doi.org/10.18535/jmscr/v7i5.15

Journal Of Medical Science And Clinical Research

IGM Publication

An Official Publication of IGM Publication

\title{
A Comparative Study on Collagen Dressing vs Normal Dressing
}

\section{Authors}

\author{
Dr N. Junior Sundresh ${ }^{1}$, Dr S.Narendran ${ }^{2}$, Mohammad Faheem Mohiuddin ${ }^{3}$, \\ Nayana Koshy $^{4}$, K.Arunraj ${ }^{5}$, S.Sowmiya ${ }^{6}$, Shaik Mohammed Sameer ${ }^{7}$ \\ ${ }^{1}$ Professor, Department of Surgery, R.M.M.C.H, Annamalai University \\ ${ }^{2}$ Emeritus Professor in Surgery, M.G.R University \\ ${ }^{3,4,5,6,7}$ Doctor of Pharmacy, R.M.M.C.H, Annamalai University \\ *Corresponding Author \\ Dr N.Junior Sundresh \\ Professor, Department of Surgery, R.M.M.C.H, Annamalai University \\ Email: juniorsundresh@gmail.com
}

\begin{abstract}
Background: The study conducted was observational and comparative study in patients suffering from diabetic foot ulcer. The purpose of the study was to observe the effectiveness in healing of normal dressing and dressing with collagen powder in the Surgery Department at Rajah Muthiah Medical College \& Hospital (RMMC \& $H$ ).

Methods: The study was conducted from the record of the patient's case sheets in tertiary care teaching hospital. A total of 55 patients were including in this study over 4 months period (2018 June - September). 55 patients were found to be with diabetic foot ulcer. The required data for this condition are obtained from the available case sheets.

Results: The total number of patients observed is 55. A total of 55 patients belonging to the various age groups were include in the study, Out of which 4 patients belong to the age group 40-49 years (7.77\%), 11 patients belong to the age group 50-59 years (20.0\%), 16 patients belong to the age group 60-69 years (29.09\%), 25 patients belong to age group >70 years (43.63\%). Among these 34 patients were males and 21 patients were females. Out of 55 patients 25 patients had received collagen powder dressing and 30 patients had received normal dressing. To examine the relationship between pain and wound healing, pain levels were compared in subjects who received collagen powder dressing and normal dressing.

Conclusion: We found high number of males (61.81\%) had foot ulcers when compared to females (38.18). The prevalence of the diabetic foot ulcer progressively increases with increasing age. This study shows that collagen powder dressing increasing the healing rate when compared with the normal dressing in diabetic foot ulcer patients.

Keywords: Diabetes, Diabetic foot, Visual Analogue scale, Collagen dressing, Normal dressing, Wound healing.
\end{abstract}

\section{Introduction}

Diabetes $^{[1]}$ is a disease which occurs when glucose or sugar levels are too high in blood. It is a condition in which the pancreas stops producing enough insulin or when glucose in the blood won't get absorbed into the cells of the body due 
to no response of cells to the insulin that is produced.

3 Types of Diabetes Mellitus:

Type 1 Diabetes Mellitus

Type 2 Diabetes Mellitus

Gestational Diabetes Mellitus

Type 1 Diabetes mellitus

It's also known as insulin-dependent diabetes. Type 1 is usually caused by destructive nature of body's own immune system on the islets of Langerhans of the pancreas, which occurs mistakenly when it normally fights against harmful bacteria and viruses. Genetics and exposure to viruses and other environmental factors are also other possible causes of type1 diabetes. Sugar builds up in the bloodstream if there is no insulin to allow glucose into the cells which can even cause life threatening complications. Complications like it can affect major organs like heart, blood vessels, nerves, eyes and kidneys.

\section{Type 2 Diabetes mellitus}

It's also known as adult onset diabetes. Type 2 is caused in which the beta cells of the pancreas produce insulin but the body is unable to use it effectively because the cells of the body are resistant to the action of insulin. It is the most common form of diabetes.

\section{Gestational Diabetes mellitus}

Gestational Diabetes is a short-term condition associated with pregnancy, in which blood glucose levels increase during pregnancy but usually return to normal after delivery.

Diabetic foot ulcer most commonly occurs in people who have type 1 or type 2 diabetic mellitus. It is an open sore or wound which is commonly localized on the bottom of the foot. Around 5 to 6 percent of people who develop a foot ulcer get hospitalized due to infection or any other complications related to ulcer.
Types of Dressing for Diabetes Mellitus

- Moist to Moist dressing.

- Hydrogels/Hydrocolloids.

- Alginate dressings

- Collagen wound dressing

- Debriding agents

- Antimicrobial dressings

- Composite dressings

- Synthetic skin substitutes

Various group of low adherence or saline soaked gauze dressings are often considered as the standard treatment for diabetic foot ulcers. These dressings are simple relatively inexpensive and provides a moist wound environment. These are not only used for managing infections but also can be safely used in synchrony with antibiotic treatment.

\section{Collagen Powder ${ }^{[2]}$}

Collagen Powder consists of hydrolyzed modified collagen which dissolves to form a protective gel when sprinkled in the wound. The following are its benefits:

1. Natural enzymes present in wound fluids breaks down the collagen powder.

2. To protect from dehydration it forms a protective gel on the wound bed.

3. No need to be replaced from wound site.

4. Provides moist wound healing environment.

5. Non-toxic and non-irritating.

6. Easy to use.

\section{Visual analogue scale}

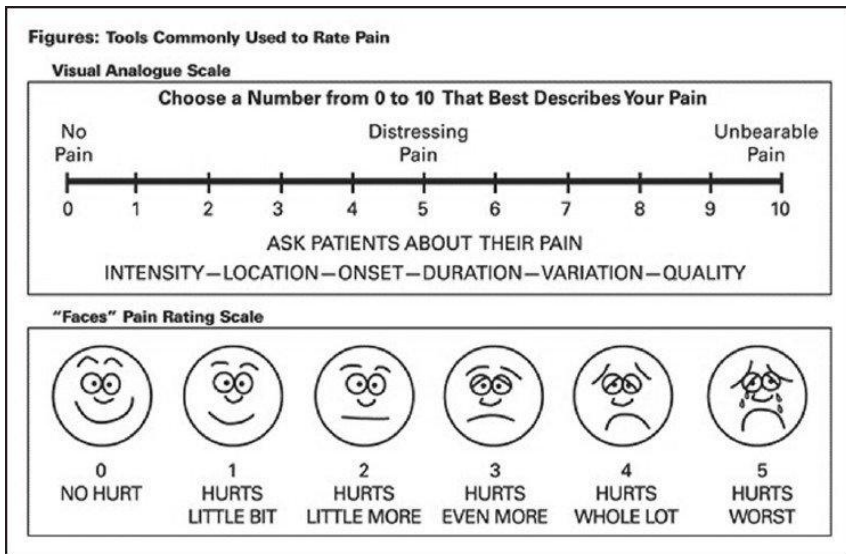


To measure subjective characteristics or attitudes psychometric response scale like visual analogue scales are used in the past for multiple disorders and social science investigations among others. VAS were first described in 1921 and referred to at the time as a "graphic rating method" ${ }^{[5]}$. The initial publication, which covered only one page, was presented as a new method for management personnel to evaluate the workers assigned to them ${ }^{[3]}$

The topic of VAS was addressed by psychological publications and socio-medical until 1940s. In 1960s the literature showed interest in the use and study of VAS ${ }^{[3,6]}$.

The word "visual" in the term visual analogue scale emphasizes the nature of this scale.

The word "analogue" stresses the infinitely variable, continuously changing response format. As a result, and particularly since the advent of computer technology, a verbal distinction to "digital" is made, whereby there is always a stepwise change per Bit.

Therefore the meaning of VAS is that it is classless and permits an infinite number of gradations between endpoints [7] whereas the categorical scale which is entirely different as they donot permit intermediate evaluation and in extreme cases provide only two modalities ("Yes" - "No") ${ }^{[3]}$.

VAS scores can also be classified retrospectively, by creating value groups. Their data are considered interval-scaled, that is the main advantage of VAS. To calculate the arithmetic mean, two equally sized intervals on a VAS are always interpreted as two equally sized difference by respondents.

Data obtained from categorical scales, can only be interpreted in terms of their dissimilarity and rank; as such, the data are ordinal-scaled. Although the categories reflect a hierarchy, there is no statement to show how large the differences between the individual categories are for a respondent. Therefore, here it is only permissible to give median values.

\section{Methodology}

Study Type: Observational and comparative study.

Study Place: The study was conducted in Surgery Department, Rajah Muthiah Medical College and Hospital, Annamalai University, Annamalai Nagar, Tamil Nadu, which is a 1400 bedded multi-speciality tertiary care teaching hospital located in rural South India.

\section{Study Recruitment Procedure}

The recruitment of subjects was carried out with the help of physician who has the knowledge of the patient's medical history.

* The selected subjects were the patients who were referred to or admitted in the Surgery department at RMMCH and the follow up taken for the period of 3 months.

* The study procedure was completely explained to the patients and informed consent was obtained from them.

Patients included in the study were selected based on Inclusion and exclusion criteria.

\section{Inclusion Criteria}

$\checkmark$ Diabetic patients who were suffering with Diabetic foot ulcer.

$\checkmark$ Patients who use and don't use collagen powder in there dressing were taken.

\section{Exclusion Criteria}

$\checkmark$ Patients who are not willing to participate in the study.

$\checkmark$ Patients suffering from other types of Diabetes Mellitus without Diabetic foot ulcer.

\section{Study Method:}

* The Study was conducted in the department of surgery at RMMCH, a 1400 bedded multispecialty tertiary care teaching hospital.

* The study method involves selection of patients based on the inclusion and exclusion criteria.

* Interpretation of results.

* Report writing.

* Conclusion of report.

* Collected data will be stored in department library for future reference in the form of thesis book. 
Results and Discussion

1. Age Wise Distribution

\begin{tabular}{|l|c|c|c|}
\hline S. No & Age in years & No. of Patients & Percentage \\
\hline 1 & $40-49$ & 4 & $7.77 \%$ \\
\hline 2 & $50-59$ & 11 & $20 \%$ \\
\hline 3 & $60-69$ & 16 & $29.09 \%$ \\
\hline 4 & $>70$ & 24 & $43.63 \%$ \\
\hline & Total & 55 & $100 \%$ \\
\hline
\end{tabular}

A total No: of 55 patients were included in the study out of which 4 patients are in the age group of $40-49$ years $(7.77 \%), 11$ patients are in the age group $50-59$ years $(20 \%), 16$ patients are in the age group of $60-69$ years (29.09\%), 24 patients are in the age group of $>70$ years $(43.63 \%)$.

\section{Gender Wise Distribution}

\begin{tabular}{|l|c|c|c|c|}
\hline S. No & Male & Percentage & Female & Percentage \\
\hline 1 & 34 & $61.81 \%$ & 21 & $38.18 \%$ \\
\hline
\end{tabular}

Out of 55 patients 34 patients were males $(61.81 \%), 21$ patients were females $(38.18 \%)$

\section{Collagen Dressing vs Normal Dressing}

\begin{tabular}{|l|c|c|c|c|}
\hline S. No & $\begin{array}{c}\text { No. of patients using } \\
\text { collagen dressing }\end{array}$ & Percentage & $\begin{array}{c}\text { No. of patients using } \\
\text { normal dressing }\end{array}$ & Percentage \\
\hline 1 & 25 & 45.4 & 30 & 54.5 \\
\hline
\end{tabular}

A total no. of 55 patients were included in the study, out of which 25 patients used collagen powder in there dressing and 30 patients cannot afford the collagen powder and did not use collagen powder in there dressing.

\section{Visual Analogue Scale}

\begin{tabular}{|l|c|c|c|}
\hline S. No & Factors & $\begin{array}{c}\text { Avg. pain score in } \\
\text { collagen dressing }\end{array}$ & $\begin{array}{c}\text { Avg. pain score in } \\
\text { normal dressing }\end{array}$ \\
\hline 1 & First \& Second week & 8 & 8 \\
\hline 2 & Third \& Fourth week & 4 & 6 \\
\hline 3 & Fifth \& Sixth week & 2 & 5 \\
\hline
\end{tabular}

This shows that pain was severe in most of the patients during first week. By using a systematic approach based on Visual Analogue pain rating scale, we documented improved overall wound healing outcome in 55 patients suffering from diabetic foot ulcer by using 10 points numerical rating scale (Average level of pain is reduced from first week to sixth week). To examine the relationship between pain and wound healing pain levels were compared from first week to sixth week, out of which 25 patients used collagen powder and 30 patients cannot afford the collagen powder and did not use collagen powder in there dressing. Wound healing was faster in the patients using Collagen powder in their dressing compared to that of the patients using normal dressing.

\section{Conclusion}

1. We found high number of males $(61.81 \%)$ had foot ulcers when compared to females (38.18\%).

2. The prevalence of the diabetic foot ulcer progressively increases with increasing age.

3. This study shows that collagen powder dressing increasing the healing rate when compared with the normal dressing in diabetic foot ulcer patients. 


\section{References}

1. https://www.who.int/mediacentre/factsheets/f s138/en/

2. https://wellnessmama.com/3058/collagenhydrolysate/

3. Funke F. Vergleich Visueller Analogskalenmit Kategorialskalen in Offlineund Online-Design. Magisterarbeitim Studiengang Soziologie am Institutfür Soziologie des FachbereichsSozial- und Kulturwissenschaften der Justus-LiebigUniversität Gießen. 2004. [Google Scholar]

4. Flynn D, van Schaik P, van Wersch A. A comparison of multi-item likert and visual analogue scales for the assessment of transactionally defined coping. Eur J Psychol Assess. 2004;20:49-58. doi: 10.1027/10155759.20.1.49. [Cross Ref] [Google Scholar]

5. Hayes MHS, Paterson DG. Experimental development of the graphic rating method. Psychol Bull. 1921;18:98-99. [Google Scholar]

6. Aitken RC. Measurement of feelings using visual analogue scales. Proc R Soc Med. 1969; 62:989-993. [PMC free article] [PubMed] [Google Scholar]

7. Baur N. Bivariate Statistik, Drittvariablenkontrolle und das Ordinalskalen problem. Eine Einführung in die Kausalanalyse und in den Umgangmitzwei dimension alen Häufigkeits verteilungenmit SPSS für Windows. Bamberg: OttoFriedrich-Universität; 2003. [Google Scholar]

8. Brunier G, Graydon J. A comparison of two methods of measuring fatigue in patients on chronic haemodialysis: visual analogue vsLikert scale. Int J Nurs Stud. 1996;33:338348. doi: 10.1016/0020-7489(95)00065-8. [PubMed] [CrossRef] [Google Scholar] 